\title{
Effects of biopraparites on cynara scolymus L., micro and macroelements, and quantity of flavonoids
}

\author{
Mukaddas Sobirova ${ }^{1, *}$ and Sayyora Murodova $^{2}$ \\ ${ }^{1}$ Jizzakh Polytechnic Institute, Jizzakh province, Uzbekistan \\ ${ }^{2}$ Tashkent State Agrarian University, Universitetskaya str., 2, 100140, Tashkent, \\ Uzbekistan
}

\begin{abstract}
Abstact. In this study, the effect of "Zamin-M" biopreparation on the content of some macronutrients, microelements and flavonoids in the leaf extract of thorny artichoke (Cynara scolymus L) belonging to the family Asteraceae was determined by 4 different factors: control, mineral fertilizer, biopreparation, biopreparation study and mineral fertilizer. The order of decreasing the concentration of macro-microelements in the control variant changed for $\mathrm{K}>\mathrm{Na}>\mathrm{Ca}>\mathrm{Mg}>\mathrm{P}$ and $\mathrm{Fe}>\mathrm{Si}>\mathrm{Al}>\mathrm{Mn}>\mathrm{Zn}>\mathrm{Cu}>\mathrm{Se}>\mathrm{Co}$. In plants treated with "Zamin-M" biopreparation, changes in $\mathrm{Ca}>\mathrm{Na}>\mathrm{Mg}>\mathrm{K}>\mathrm{P}$ and $\mathrm{Fe}>\mathrm{Al}>\mathrm{Si}$ $>\mathrm{Mn}>\mathrm{Zn}>\mathrm{Cu}>\mathrm{Co}>\mathrm{Se}$ were found. When determining the effect of Zamin-M biopreparation on the flavonoids in artichoke leaves, it was noted that the amount of quercetin in plants increased by $93.05 \%$ compared to plants treated with mineral fertilizers. The amount of rutin was increased by $54.94 \%$ in plants treated with "Zamin-M", it was $57.55 \%$ in plants treated with mineral fertilizers, and it was $59.60 \%$ in plants treated with mineral fertilizers + "Zamin-M" biopreparation.
\end{abstract}

\section{Introduction}

In recent years, more and more attention has been paid to the study of nutrition and its impact on the development of chronic degenerative diseases. Prevention can play an important role in the nutrition of the population and thus reduce the risk factors affecting health [3-6]. Some fruits and vegetables are rich in polyphenols, biologically active secondary metabolites (flavonoids, phenolic acids, hydroxycinamic acids, lignans) with very high structural diversity that make up different groups. The beneficial properties of prickly artichoke [1] have been known since ancient times [13] and are now widely used in world medicine as well as being an important food source for the Mediterranean population $[1,2]$. The pharmaceutical properties of artichokes depend on its specific chemical composition, they contain large amounts of cynarin from polyphenolic compounds and its biosynthetic product is chlorogenic acid $[14,15]$. It is also a natural functional nutrient rich in inulin, plant fiber and minerals $[4,5]$. Artichoke leaves and buds have a positive effect on total cholesterol levels in the blood and lower triglyceride levels and increase glutathione peroxide levels [15]. In addition, artichoke leaf extracts have antioxidant, anticarcinogenic, antiviral immune deficiency effects; have bile driving and

\footnotetext{
* Corresponding author: muk4ddas.sobirova@yandex.ru
} 
hepatoprotective properties, as well as antifungal and antibacterial properties [1, 4-9]. Artichoke extract can be added mainly to meat to flavor food and protect it from lipid and protein oxidation. Interest in artichoke extract is due to its multifaceted therapeutic effect. The most characteristic effect is the stimulation of bile secretion. The extracts have a diastolic effect on the gallbladder and bile ducts, leading to an increase in bile production by liver cells $[3,15]$.

The addition of artichoke stem powder (ASP) to the dough during baking significantly changes the quality and appearance of the bread, as well as significantly increases the amount of total phenolic compounds in the bread [2, 3, 14]. Many beneficial properties of artichoke extract have led to an increase in demand for it and contributed to its spread in Europe and many other countries [10-12].However, there are factors that negatively affect the genetic structure of prickly artichokes, including biotic and abiotic stresses. Today, the growing demand for medicinal artichokes requires the reduction of the amount of inorganic fertilizers that adversely affect the soil structure in their cultivation and the use of biological agents isolated based on local strains. This is because excessive use of nitrogen fertilizers usually leads to the total cost of growing this plant and pollution of the agroecosystem [7, 8]. Bacterial preparations are environmentally friendly and contain beneficial microorganisms. When the planting material of plants is treated with the drug, artificially infecting the beneficial microflora on the surface of the seed is achieved. When seeds treated with biopreparation are sown, the bacteria on its surface begin to grow rapidly and multiply, actively occupying the plant rhizosphere and synthesizing substances that inhibit the growth of pathogenic microorganisms in their vital activity and have a positive effect on the development of beneficial microorganisms $[2,6,7]$. The aim of the study was to study the effect of a biopreparation on the micro and macronutrients of L., a leaf extract of thorny artichoke (Cynara scolymus L) belonging to the family Asteraceae, the amount of flavonoids.

\section{Materials and methods}

The research was conducted at the experimental site of the Polytechnic Institute in Jizzakh, Jizzakh region of Uzbekistan. The research material consists of a set of strains called B.subtilis SKB-309, B.megaterium SKB-310, P.stutzeri SKB-308 (Patent - IAP 20140021), recommended by S.S. Muradova and others. Zamin-M (dry and liquid forms) and thorny artichoke (Cynara scolymus L) leaf extract of the Asteraceae family were taken $[1,11,15]$.

Prior to the study, the composition of the agrochemical and chemical parameters of the soils of the experimental area was studied. The amount of humus in the soil agrochemical analysis was determined by the Tyurin method, total nitrogen, phosphorus, [11-14] method, nitrate nitrogen, mobile phosphorus, and exchangeable potassium It was detected on an flammable photometer. Agrochemical analysis of soil was carried out in collaboration with the staff of the Agrochemical Laboratory of the Institute of Soil Science of the Republic of Uzbekistan (Tables 1 and 2). The experiments were carried out on the basis of 4 factors, the first factor is control, the second factor - $100 \%$ chemical fertilizer at the level of NaNO3 $(100 \mathrm{~kg} / \mathrm{ha})$, the third factor - biological product "Zamin-M" in the amount of 1 liter per 1 ha, the fourth factor 50\% chemical fertilizer and bioproducts [12-15]. Before sowing, the plant seeds were treated with a bioproduct and the effect of fertilizers on the chemical composition of the plant was studied. 
Table 1. Agrochemical analysis of soil.

\begin{tabular}{|c|c|c|c|c|c|c|c|c|c|c|c|}
\hline \multirow[b]{2}{*}{ ô. } & \multirow[b]{2}{*}{ 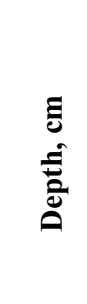 } & \multirow{2}{*}{ 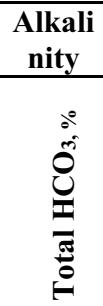 } & \multirow[b]{2}{*}{ 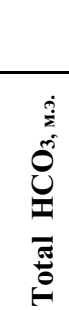 } & \multicolumn{2}{|c|}{ Cl } & \multicolumn{2}{|c|}{$\mathrm{SO}_{4}$} & \multicolumn{2}{|c|}{ Ca } & \multicolumn{2}{|c|}{$\mathbf{M g}$} \\
\hline & & & & $\partial^{\circ}$ & 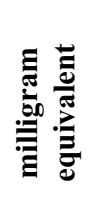 & $\partial^{0}$ & 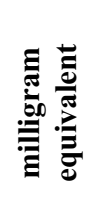 & $\partial^{0}$ & 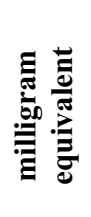 & $\partial^{\theta}$ & 焉 \\
\hline 1 & $0-10$ & 0.027 & 0.44 & 0.007 & 0.2 & 0.039 & 0.81 & 0.012 & 0.6 & 0.004 & 0.3 \\
\hline 2 & $10-30$ & 0.027 & 0.44 & 0.007 & 0.2 & 0.026 & 0.54 & 0.008 & 0.4 & 0.002 & 0.2 \\
\hline 3 & $30-50$ & 0.024 & 0.4 & 0.007 & 0.2 & 0.036 & 0.75 & 0.01 & 0.5 & 0.002 & 0.2 \\
\hline 4 & $\begin{array}{l}50-70 \\
\end{array}$ & 0.027 & 0.44 & 0.007 & 0.2 & 0.03 & 0.62 & 0.008 & 0.4 & 0.002 & 0.2 \\
\hline 5 & $70-100$ & 0.024 & $\begin{array}{l}0.4 \\
\end{array}$ & 0.007 & 0.2 & 0.036 & 0.75 & 0.01 & 0.5 & 0.004 & 0.3 \\
\hline
\end{tabular}

Table 2. Agrochemical analysis of soil.

\begin{tabular}{|c|c|c|c|c|c|c|c|c|c|c|}
\hline$\stackrel{\tilde{a}}{0}$ & 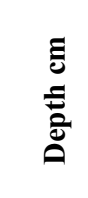 & 涪 & Uే & 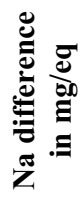 & 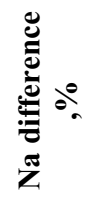 & 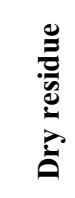 & 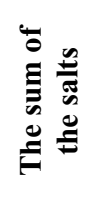 & 핌 & |્| & రుlర્心 \\
\hline 1 & $0-10$ & 1.45 & 0.9 & 0.55 & 0.013 & 0.094 & 0.088 & 8.9 & 0.24 & 0.24 \\
\hline 2 & $10-30$ & 1.18 & 0.6 & 0.58 & 0.013 & 0.076 & 0.07 & 8.9 & 0.23 & 0.36 \\
\hline 3 & $30-50$ & 1.35 & 0.7 & 0.65 & 0.015 & 0.09 & 0.083 & 8.88 & 0.23 & 0.26 \\
\hline 4 & $50-70$ & 1.26 & 0.6 & 0.67 & 0.015 & 0.082 & 0.076 & 8.83 & 0.19 & 0.32 \\
\hline 5 & $70-100$ & 1.35 & 0.8 & 0.55 & 0.013 & 0.088 & 0.081 & 8.79 & 0.24 & 0.26 \\
\hline
\end{tabular}

Analysis of macro and microelements and flavanoids was conducted at the Institute of Bioorganic Chemistry of the Russian Academy of Sciences. In the quantitative determination of macro- and micronutrients by inductively coupled plasma mass spectrometry (ICP-MS), a sample of the test substance was weighed on an analytical balance with an accuracy of $0.0500-0.5000 \mathrm{~g}$ and transferred to Teflon containers (ISP MS Nexion-2000 (Perkin Elmer USA)). The vessels were then filled with appropriate amounts of purified concentrated mineral acids (nitric acid (chemically pure) and hydrogen peroxide (chemically pure) level and number of samples were indicated (up to 12).

After disintegration, the contents of the vials were quantitatively transferred to 50 or 100 $\mathrm{ml}$ volumetric flasks, and given by volume with $2 \%$ nitric acid [6, 7-9]. In compiling the sequence of analyzes, the amount in $\mathrm{mg}$ and its dilution rate in $\mathrm{ml}$ were indicated. After receiving the data, the device automatically calculated and entered the actual amount of substance in the tested sample in the form of $\mathrm{mg} / \mathrm{kg}$ or $\mathrm{mkg} / \mathrm{g}$ with error limits - RSD percentage [1-3, 11]. Apparatus and containers used: ISP MS Nexion-2000 (Perkin Elmer USA or similar, microwave decomposer Berghoffc (Germany) or similar Teflon autoclaves, volumetric flasks. Reagents used: multi-element standard № 3 (for 29 elements for ECO), standard - Hg (mercury for ECO), nitric acid (x/t), hydrogen peroxide (q/h), distilled water, argon (gas frequency $99.995 \%$ ). 


\section{Results and discussion}

The amount of hand in the control was $134,914 \mathrm{mg} / \mathrm{kg}$, which is $89.95 \%$ compared to the control in the plants treated with "Zamin-M", 49.51\% compared to the control in the plants treated with mineral fertilizers, 35 in the plants treated with mineral fertilizers + "ZaminM". The highest levels of Al element in plant composition were observed in plants treated with "Zamin-M". The amount of "As" in the control was $0.0012 \mathrm{mg} / \mathrm{kg}$, in plants treated with "Zamin-M" by $20 \%$ compared to control, in plants treated with mineral fertilizers by $57.14 \%$ compared to control, in plants treated with mineral fertilizers + "Zamin-M" increased by $36.84 \%$ compared to controls.

The amount of "Ba" was $1.457 \mathrm{mg} / \mathrm{kg}$ in the control, and in plants treated with "ZaminM" increased by $11.91 \%$ compared to the control, treatment with mineral $(1.451 \mathrm{mg} / \mathrm{kg})$ and mineral fertilizers + "Zamin-M" $(1.325 \mathrm{mg} / \mathrm{kg})$ found a slight decrease in control over the given plants. It can be seen that the amount of "Ba" was high only in plants treated with biofertilizers. The amount of "Ba" was $1.457 \mathrm{mg} / \mathrm{kg}$ in the control, and in plants treated with "Zamin-M" increased by $11.91 \%$ compared to the control, treatment with mineral $(1.451 \mathrm{mg} / \mathrm{kg})$ and mineral fertilizers + "Zamin-M" $(1.325 \mathrm{mg} / \mathrm{kg})$ found a slight decrease in control over the given plants. Evidently, the amount of "Ba" was high only in plants treated with biofertilizers. The amount of " $\mathrm{Zn}$ " in the control was $16,199 \mathrm{mg} / \mathrm{kg}$, which was $1.39 \%$ higher than in the plants treated with "Zamin-M", and 3.02\% higher than in the plants treated with mineral plants. However, this figure was $13,214 \mathrm{mg} / \mathrm{kg}$ in the plants, which treated with mineral fertilizers + "Zamin-M".

The amount of "Ca" in the control was $6092,734 \mathrm{mg} / \mathrm{kg}$, which was $48.6 \%$ higher in the plants treated with Zamin-M, and $25.32 \%$ higher in the plants treated with minerals. "Cu" was $4.069 \mathrm{mg} / \mathrm{kg}$ in the control, and the plants treaded with "Zamin-M" had $5.120 \mathrm{mg} / \mathrm{kg}$. According to the results obtained, the use of biofertilizer to achieve an increase in the content of $\mathrm{Cu}$ in the composition of prickly artichokes gave good results. The highest amount of Fe was observed in the plant treated with "Zamin-4", which was 2086.231 $\mathrm{mg} / \mathrm{kg}$, whereas the lowest one was found in the control, accounted for $320.510 \mathrm{mg} / \mathrm{kg}$. The highest amount of Li was $3.689 \mathrm{mg} / \mathrm{kg}$ in the plant treated with "Zamin-4", and the lowest one was in the control and the plant treated with combination of minerals and "Zamin-4". Moreover, the plant treated with "Zamin-4" had the highest amount Mg, which was $3129.033 \mathrm{mg} / \mathrm{kg}$, whereas the highest amount of Mn was found in the plant treated with minerals+"Zamin-4". "Zamin-4" had positive effect on the plants, accordingly, the highest amount of $\mathrm{Si}$ and Co was observed in the plant, which was $969.574 \mathrm{mg} / \mathrm{kg}$ and 0.892 $\mathrm{mg} / \mathrm{kg}$, respectively. However, the plants treated with minerals had the highest amount of $\mathrm{Hg}$, accounted for $0.0022 \mathrm{mg} / \mathrm{kg}$, and the rest of the plants treated with "Zamin-4" and Minerals + "Zamin-4" had the lower indicator (Table 3). 
Table 3. The amount of micro and macronutrients in the raw material.

\begin{tabular}{|c|c|c|c|c|c|}
\hline$\#$ & Elements & Control & Zamin-4 & Minerals & Mineral+Zamin-4 \\
\hline 1 & $\mathrm{Al}$ & 134.914 & 1342.83 & 267.203 & 208.477 \\
\hline 2 & $\mathrm{As}$ & 0.0012 & 0.0015 & 0.0028 & 0.0019 \\
\hline 3 & $\mathrm{Ba}$ & 1.457 & 1.654 & 1.451 & 1.325 \\
\hline 4 & $\mathrm{Zn}$ & 16.199 & 16.427 & 16.703 & 13.214 \\
\hline 5 & $\mathrm{Ca}$ & 6092.734 & 11853.013 & 8159.046 & 5210.731 \\
\hline 6 & $\mathrm{Cd}$ & 0.0083 & 0.0094 & 0.0091 & 0.0059 \\
\hline 7 & $\mathrm{Cu}$ & 4.069 & 5.120 & 4.839 & 4.277 \\
\hline 8 & $\mathrm{Fe}$ & 320.510 & 2086.231 & 485.253 & 340.582 \\
\hline 9 & $\mathrm{Li}$ & 1.686 & 3.689 & 2.359 & 1.178 \\
\hline 10 & $\mathrm{Mg}$ & 2204.130 & 3129.033 & 2212.887 & 1973.644 \\
\hline 11 & $\mathrm{Mn}$ & 20.019 & 57.464 & 21.003 & 16.666 \\
\hline 12 & $\mathrm{Hg}$ & 0.0020 & 0.0021 & 0.0022 & 0.0017 \\
\hline 13 & $\mathrm{Si}$ & 167.812 & 969.547 & 556.237 & 483.041 \\
\hline 14 & $\mathrm{Co}$ & 0.189 & 0.892 & 0.227 & 0.230 \\
\hline
\end{tabular}

Flavonoids are a well-studied group of secondary metabolites that have antioxidant, anti-cancer, and anti-inflammatory effects. Prickly artichoke is an important source of bioactive phenolic compounds, including flavonoids. The antioxidant activity of plant polyphenols is related to the presence and location of hydroxyl and methoxyl groups. The presence of flavonoids contributes to the elimination of reactive oxygen species and the chelation of metal ions. However, the total amount of phenol does not precisely determine its ability to clear free radicals or its ability to reduce iron. When determining the effect of biofertilizers on the group of phenolic compounds in artichoke leaves, the results showed that the amount of quercetin from flavonoids in the plant was not detected in the samples of control and mineral fertilizers + "Zamin-M".

The amount of quercetin in plants treated with mineral fertilizers was $0.0059 \mathrm{mg} / \mathrm{kg}$, and it was $93.05 \%$ higher in plants treated with Zamin-M biopreparation than in plants treated with mineral fertilizers. The amount of rutin in the control factor was $0.0879 \mathrm{mg} / \mathrm{kg}$, which was 54.94\% higher than in the plants treated with Zamin-M, and 57.55\% higher than in the plants treated with mineral fertilizers. In plants treated with $-\mathrm{M}$, this figure was increased by $59.60 \%$. These results showed that treatment with biofertilizers along with mineral fertilizers has a strong effect on the metabolite profile, which serves as a good factor to enhance the biosynthesis of secondary metabolites in this plant (Table 4).

Table 4. Effect of Zamin-M bioreparation on some flavonoids of artichoke leaf extract.

\begin{tabular}{|c|c|c|c|}
\hline \multirow{2}{*}{$\#$} & \multirow{2}{*}{ Factors } & \multicolumn{2}{|c|}{ Detected concentration\% } \\
\cline { 3 - 4 } & & Quercetin & Rutin \\
\hline 1 & Control & - & 0.0879 \\
\hline 2 & Minerals & 0.0059 & 0.2071 \\
\hline 3 & Minerals+Zamin-4" & - & 0.2176 \\
\hline 4 & "Zamin-4" & 0.0085 & 0.1951 \\
\hline
\end{tabular}




\section{Conclusions}

The amount of macronutrients in the studied artichoke plant raw materials in the samples was as follows: in the control variants in the order $\mathrm{K}>\mathrm{Na}>\mathrm{Ca}>\mathrm{Mg}>\mathrm{P}$, micronutrients $\mathrm{Ca}>\mathrm{Fe}>\mathrm{Si}>\mathrm{Al}>\mathrm{Mn}>\mathrm{Zn}>\mathrm{Cu}>\mathrm{Se}>\mathrm{Co}$ in descending order. In plants treated with Zamin-M biopreparation, macronutrients were arranged in descending order as $\mathrm{Ca}>\mathrm{Na}>\mathrm{Mg}>\mathrm{K}>\mathrm{P}$, and micronutrients were arranged in descending order as $\mathrm{Fe}>\mathrm{Al}>\mathrm{Si}>\mathrm{Mn}>\mathrm{Zn}>\mathrm{Cu}>\mathrm{Co}>\mathrm{Se}$. In plants treated with mineral fertilizers, macronutrients were arranged in descending order as $\mathrm{Na}>\mathrm{Ca}>\mathrm{K}>\mathrm{Mg}>\mathrm{P}$, micronutrients in descending order as $\mathrm{Si}>\mathrm{Fe}>\mathrm{Al}>\mathrm{Mn}>\mathrm{Zn}>\mathrm{Cu}>\mathrm{Co}>\mathrm{Se}$. In plants treated with mineral fertilizer + "Zamin-M", macronutrients were in descending order as $\mathrm{Na}>\mathrm{K}>\mathrm{Ca}>\mathrm{Mg}>\mathrm{P}$, and micronutrients were in descending order as $\mathrm{Si}>\mathrm{Fe}>\mathrm{Al}>\mathrm{Mn}>\mathrm{Zn}>\mathrm{Cu}>\mathrm{Co}>\mathrm{Se}$.

Trace elements such as $\mathrm{Zn}, \mathrm{Mn}$, Se and Fe were played important roles in combating oxidative stress as enzymatic protective components. Treatment with "Zamin-M" biopreparation and Mineral fertilizer + "Zamin-M" resulted in an increase in trace elements such as Fe, $\mathrm{Zn}, \mathrm{Mn}$, Se relative to the control. The amount of flavonoids in the studied samples was as follows: cynaroside>rutin in the controlled plants, rutin $>$ cynaroside $>$ quercetin in plants treated with Zamin-M biopreparation, cynaroside $>$ rutin $>$ quercetin in plants treated with mineral fertilizers, mineral fertilizers + treated with "Zamin-M" biopreparation in plants> a change in the order, such as cynaroside, was noted.

\section{References}

1. V. Angelova, M. Nemska, L. Krustev, AGROFOR Int. J, 4 (2019)

2. N. Teshaev, B. Mamadaliyev, A. Ibragimov, S. Khasanov, InterCarto. InterGIS, 26(3), 324-333 (2020)

3. A. Gatto, D. De Paola, F. Bagnoli, G. Vendramin, G. Sonnante, Ann. Bot., 112, 10 (2013)

4. F. Sofi, C. Macchi, R. Abbate, F. Gensini, A. Casini, Biofactors, 39 (2013)

5. X. Zhua, H. Zhanga, R. Lob, Fitoterapia, 76 (2005)

6. W. Biel, R. Witkowicz, E. Piątkowska, C. Podsiadło, Biological trace element research, 194, 2 (2020)

7. H. Shimoda, K. Ninomiya, N. Nishida, T. Yoshino, T. Morikawa, H. Matsuda, Bioorg. Med. Chem. Lett., 13, 9 (2003)

8. M. Rondanelli, A. Giacosa, A. Opizzi, M. Faliva P. Sala, S. Perna, A. Riva, P. Morazzoni, E. Bombardelli, Int J Food Sci Nutr., 64, 1 (2013)

9. Y. Behara, J. Pharm Biomed Sci., 11, 11 (2011)

10. E. Vamanu, A. Vamanu S. Niţă, S. Colceriu, Trop. J. Pharm Res., 10, 6 (2011)

11. M. Rondanelli, F. Monteferrario, S. Perna, M. Faliva, A. Opizzi, Monaldi Archives for Chest Disease, 80, 1 (2013)

12. S. Isaev, S. Khasanov, Y. Ashirov, T. Karabaeva, A. Gofirov, In E3S Web of Conferences, 244, 02012 (2021)

13. E. Heidarian, M. Rafieian-Kopaei, Pharm Biol., 51 (2013)

14. R. Kulmatov, A. Taylakov, S. Khasanov, Environmental Science and Pollution Research, 28(10), 12245-12255 (2021)

15. I. Aslanov, S. Khasanov, Y. Khudaybergenov, M. Groll, Ch. Opp, F. Li, E. Ramirez Del-Valle, In E3S Web of Conferences, 227, 02005 (2021) 